\title{
Geografie sociální exkluze
}

\section{Geography of Social Exclusion}

\author{
Michal Rưžička
}

ABSTRACT Social exclusion as a form and a manifestation of inter-group relations, is an unwatched but seemingly indivisible aspect of social life in modern cities. The process of sociospatial exclusion touches people who are conceptualised as members of a 'different' ethnic group. People of 'different ethnicity', or Roma in the socio-cultural context of Czech cities are concentrated and separated into spatially excluded places. This process takes place on the municipal level mainly through the process of allocating 'social housing'. People defined as 'different' are being put into places to places that have a special positioning within the spatial imagination of the given excluding society. These 'other places' can take the form of prisons, mental hospitals or in our case urban ghettos. The author understands the genesis of urban ghettos in Czech cities as the result of social and spatial control of the dominant cultural order via excluding 'the other'. The 'Other' or Roma in the socio-cultural context of Czech cities, tend to occupy [or tend to be placed into] 'other places' of social and spatial imagination of the excluding society. The process of socio-spatial exclusion nonetheless is not seen as an unavoidable process and in the author's opinion could be controlled by more inclusive and sensitive urban planning and spatial management.

KEY WORDS ethnic segregation, social control, social exclusion, spatial exclusion

\section{1. Úvod}

Naše doba je dobou, v níž na sebe prostor bere podobu vztahů mezi umístěnými.

(Foucault 1996 [1967]: 73)

Urbanismus lze, krom jiného, považovat za způsob organizace společnosti a prostoru, za kontext, ve kterém se sociální struktura promítá do fyzického prostoru. Urbánní prostory se na první pohled mohou zdát být pouhými nádobami, ve kterých dochází k sociálnímu jednání, něčím, co pasivně poskytuje fyzický rámec pro sociální interakci. (Urbánní) Prostory jsou však místy, jež jsou sociálně organizovány: ,prostor sám o sobě může být primordiálně daný, ale organizace a význam prostoru je výsledkem sociálního překladu, transformace a zkušenosti... podobně jako dějiny reprezentují sociální transformaci času“ (Soja 1989: 80). Na sociální podmíněnost organizace fyzického prostoru upozornil již Émile Durkheim: „dělení prostoru je... u každé společnosti jiné, což je důkazem toho, že se nezakládá na vrozené lidské přirozenosti““ (Durkheim 2002 [1912]: 19), čímž podpořil svoji a Maussovu dřívější tezi o tom, že konceptualizace prostoru odpovídá sociální struktuře př́islušné společnosti (Durkheim, Mauss 1963 [1903]: 88). I v tomto textu tak nebude prostor chápán jako problém ontologický, nýbrž jako problém politický (Rabinow 2003: 355).

Sociální studia. Fakulta sociálních studií Masarykovy univerzity, 2/2006. S. 117-132. ISSN 1214-813X. 
Z hlediska socio-prostorové dialektiky, postulující vzájemný vztah mezi sociální strukturou a fyzickým prostorem, za jejíhož mluvčího lze považovat Edwarda Soju (1980), není urbánní prostor pouhým objektivním a fyzikálně neutrálním kontextem společnosti, nýbrž nedílnou součástí tohoto kontextu a jeho aktivním, nebo dokonce „represivním“ (Lefebvre 2003 [1970]: 181) činitelem. Michel Foucault v rozhovoru s Paulem Rabinowem prohlásil, že je dokonce „trochu svévolné oddělovat praxi sociálních vztahů od prostorového uspořádání, kde se odehrávají..., jedno se dá pochopit pouze prostřednictvím druhého“ (Foucault 2000 [1983]: 34).

Předpokládaje existenci určitého vztahu mezi sociální strukturou a prostorem, respektive prostorovými strukturami urbánního prostředí, se domnívám, že městský prostor je obzvláště vhodným terénem pro studium takových témat, jakými jsou sociální (mezi-skupinové) vztahy, vztahy kulturní dominance a podřízenosti, hegemonie prostoru či (sociální) exkluze. Autoři, kteří pokládají prostor za jeden z hlavních faktorů organizace, integrace a segregace městských společností, mají za to, že např́íklad sociální exkluze nemůže být studována bez přihlédnutí k prostorovým aspektům tohoto procesu. Sociální exkluzi chápou jako dialektický socio-prostorový fenomén (Madanipour 2003).

Mezi cíle předkládaného textu patří pokus o představení mechanismů a kognitivních předpokladů, které proces socio-prostorové exkluze v urbánním prostředí umožňují. Půjde o pokus nahlédnout do procesu vztyčování symbolických a prostorových mezi-skupinových hranic. Socio-prostorová exkluze, jakožto disciplinární způsob organizace urbánního prostoru, pak bude představena jako specifická forma sociální kontroly.

\section{Diference a segregace}

\subsection{Diference v urbánním prostoru}

Městské prostory se od prostor ne-městských liší výraznou sociální a kulturní heterogenitou, na což ve své teorii urbanismu upozornil již Louis Wirth. Wirth považoval heterogenitu obyvatelstva, spolu s velikostí a hustotou populace, za determinující znak městského prostředí (Wirth 1938). „Absence homogenity je nejpatrnější ve městech, nebot' to jsou misty diference“ (Madanipour 2003: 184, kurzíva M. R.).

$\mathrm{Na}$ ideálně-typické rovině je možné identifikovat dva typy reakcí na vysokou kulturní diverzitu, kterou s sebou moderní velkoměsta přinášejí. První typ reakce se snaží tuto diverzitu disciplinovat, uvrhnout na ni řád, aby byla v dnešní nejisté době pochopitelná a zvládnutelná. Druhým typem reakce na vysokou kulturní diverzitu je naopak touha kulturní heterogenitu oslavovat, chránit a konzervovat (srov. Madanipour 2003: 184-185).

Když z ideálně-typické roviny sestoupíme do reality každodennosti českých měst, shledáme, že v nich pravděpodobně (stále?) vládne modernistický diskurz. K žádné adoraci kulturních diferencí zde nedochází, ba naopak: dochází v nich k segregaci a prostorové exkluzi, zejména romských skupin. Na skutečnost prostorové segregace Romů v českých městech upozorn̆uje celá řada nedávných publikací či zpráv z výzkumů (např́iklad Baršová 2002, Jára a kol. 2006, Klíčová 2004, MPSV 2006). 
Existují celé koherentní diskurzy, které operují s pojmy jako jsou „kultura“, „etnicita“, „rasa“, „původ“, „tradice“, „kultura bydlení“ apod. a které se situaci narůstající diferenciace a segregace městských společností snaží vysvětlit či ospravedlnit. Gerd Baumann (1997) v rámci konceptualizace (kulturních) diferencí odlišuje dva základní typy diskurzu: diskurz dominantní a diskurzy démotické. Démotické diskurzy reprezentují každodennost a zkušenost členů subordinovaných či exkludovaných skupin. Dominantní diskurz je naproti tomu diskurzem hegemonním, který o žité realitě mluvčích démotických diskurzů promlouvá direktivně z pozice moci. Dominantní diskurz, který prostřednictvím samosprávních struktur vládne v českých městech a který stojí v pozadí vytváření („etnicky“) segregovaných prostor, „,si představuje ,kulturní ' diference jako homologické s diferencemi ,etnických“ identit a často i ,komunit‘, definovaných na kvazi-biologických základech... Tato diskurzivní praxe redukuje kulturu a ,etnické" rozdíly na reifikované esence“ (Baumann 1997: 209). Baumann se dále domnívá, že dominantní diskurz, pokud referuje o kulturně odlišných skupinách, redukuje celou socio-kulturní komplexitu „do úžasně jednoduché rovnice: ,kultura $=$ komunita $=$ etnická identita = přirozenost" “ (Baumann 1997: 214).

Zdá se, že tato „úžasně jednoduchá“, ve svých důsledcích však pro členy subordinovaných skupin fatální, rovnice je ve své nereflexivitě uživána i dominantním diskurzem samospráv českých měst a dalšími subjekty státní organizace $\mathrm{v}$ rámci jimi pocit’ované nutnosti nějakým způsobem konceptualizovat kulturní „,odlišnost Romů“, respektive „romské kultury“, respektive „romského etnika“.

\subsection{Segregace v urbánním prostoru}

Jedním z nejčastějších způsobů, jakým se sociální exkluze projevuje v urbánním prostoru, je rezidenční segregace. Řadou autorů je dokonce považována za vrcholnou formu tohoto procesu (Ratcliffe 2004: 59). I v českých městech dochází k vytváření prostorově segregovaných lokalit, do kterých bývají systematicky sestěhovávány osoby a rodiny, jež zároveň bývají identifikovány jako „etnicky odlišné“. Podstatným momentem je zde skutečnost, že daní lidé se do těchto prostor $\mathrm{v}$ naprosté většině př́padů nestěhují ze své vlastní vůle, nýbrž jsou do nich systematicky stěhováni z vůle místních samospráv (srov. Moravec 2006; Růžička 2006; Radostný, Růžžčka 2006a). Ghetta nikdy nejsou „přirozenými prostředími“ nebo „manifestacemi lidské přirozenosti“, jak ve své kritice př́stupu Chicagské školy ke studiu ghetta uvádí Loïc Wacquant (2004).

Př́pady mechanismů a postupů, které vedou k vytváření „etnicky“ segregovaných lokalit v českých městech, jsou podrobně představeny jinde (např́iklad Klíčová 2004, Moravec 2006: 21-22). K vytváření „etnicky“ segregovaných prostor obecně dochází prostřednictvím jednání místních samospráv, jež - nevedeny žádnou centrálně organizovanou politikou boje proti sociální exkluzi - za současné neexistence jasné koncepce tzv. „sociálního“ bydlení svými rozhodnutími tyto socio-prostorově (a „etnicky“) segregované lokality často samy ustavuji (Růžička 2006). Čelíce rostoucí skupině osob a rodin, které mají problémy v socio-ekonomické sfére, se samosprávy snaží stále se zvětšující problémy „řešit“" $\mathrm{s}$ vidinou nízké ekonomické nákladnosti koncentrací těchto osob a rodin do ,jiných prostor“ (k tomuto pojmu viz dále). Tyto ,jiné prostory“, které jsou často nemovitostmi v majetku př́slušných obcí, větši- 
nou bývají ve špatném technickém stavu a nalézají se na perifériích obcí, kde „nejsou př́liš na očích“. To pak oslabuje účinnost formální i neformální sociální kontroly a napomáhá vzniku a rozvoji mj. sociálně patologických jevů. To, že jsou do takovýchto prostorově segregovaných prostor, které mívají např́klad podobu „ubytoven pro neplatiče“, holobytů, azylových domů apod., koncentrováni Romové, kterým je zároveň připisován status odlišné „etnicity“, pravděpodobně není náhodou, ač tak bývá z pozic př́slušných místních samospráv obvykle argumentováno.

Fakt, že v českých městech existují prostory, do kterých jsou systematicky koncentrováni lidé zároveň identifikovaní jako Romové, lze, krom jiného, považovat za průvodní jev tzv. institucionálního rasismu (srov. Růžička 2006: 141). Tímto termínem bývá označováno „kolektivní selhání organizace poskytnout vhodnou a profesionální službu lidem z důvodů jejich barvy pleti, kultury nebo etnického původu“ (Pierson 2002: 192). Na úrovni českých měst, jakožto poskytovatelů (sociálních) služeb a tzv. „sociálního“ bydlení, jde o zásadní selhání v oblasti poskytování profesionální služby lidem definovaným jako odlišným prostřednictvím libovolných pojmů. Řečeno jinými slovy: (většinou) etnicky definovaní žadatelé o byt (Romové) mají větši šanci získat méně ohodnocované a méně kvalitní bydlení v méně ohodnocovaných a méně kvalitních lokalitách (srov. Robinson 2002: 94). Tento proces je často spojen s procesy odehrávajícími se na trhu s bydlením, v rámci nichž jsou žadatelé, kteří jsou konceptualizováni jako jiní, směřováni do lokalit, ve kterých již nějací jiní bydlí (Ratcliffe 2004: 61).

Skutečnost, že v českých městech existují celé prostory (domy, bloky domů, ulice) umístěné v neprestižních lokalitách, do kterých jsou v rámci „objektivně“ zarámovaných systémů přidělování obecních bytů systematicky koncentrováni lidé, kteří jsou v naprosté většině prúípadů zároveň identifikováni jako Romové - jako členové odlišné „etnické“ skupiny či jako nositelé odlišného způsobu života či „kultury“ -, nelze považovat za pouhou náhodu nebo za důsledek nějakých objektivních podmínek. Jistě existuje také celá řada osob se stejným socio-ekonomickým statusem, které za Romy považovat nelze a kteří se do daných lokalit nikdy nedostanou. Zdá se, že právě konceptualizace osob jako osob odlišných a jako osob sdílejících nějakou společnou esenci je také tím, co proces socio-prostorové exkluze umožňuje.

\subsection{Konceptualizace (kulturních) diferencí}

Diskriminaci v alokaci tzv. „,sociálního bydlení“, kdy jsou žadatelé odlišováni na základě nějaké (domnělé) esence, většinou ,etnicity“, a dle tohoto odlišení je jim přidělováno bydlení v určitých prostorech, umožňuje či způsobuje několik skutečností.

Pro období pozdní modernity je dle britského sociologa Jocka Younga (1999) typická tzv. esencializace sociálních diferencí. Esencialismus ${ }^{1}$ se stává „,hlavní strategií exkluzionismu“ tím, že odděluje sociální formace na základě jejich domnělé esence (Young 1999: 104). Esencialismus se tedy na procesu sociální exkluze podílí tím, že pomáhá identifikovat a oddělovat sociální formace na základě nějaké zvnějšku jim imputované kvality, podstaty či „při-

Pojem esencialismus lze chápat jako víru v diachronně a kontextuálně neměnnou podstatu (nejen) kulturních diferencí. 
rozenosti“. Ti členové institucionálního prostředí, kteří mají vliv na alokaci tzv. „sociálního bydlení" a kteří se podílejí na segregaci a kumulaci lidí domněle sdílejících stejnou esenci, často tvrdí, že tito lidé si údajně sami přejí budovat enklávy jako vědomé strategie udržování „tradiční“ kultury a sociálních sítí (srov. Ratcliffe 2000: 174). V analýzách diskriminace a exkluze $\mathrm{v}$ oblasti bydlení se $\mathrm{v}$ souvislosti s tímto fenoménem hovoří o propojenosti konceptů „identity“ a „same race placement“ (Young 1999: 106), což, zdá se, v plné míře platí i pro institucionální prostř̌edí českých měst. Co se týče konceptualizace Romů v rámci institucionálního prostředí (nejen) českých měst, bezezbytku zde dochází svého naplnění poznatek Marka Jakoubka, že jednu z klíčových komponent dominantního diskurzu o Romech tvoří představa o esenciálním vymezení dané skupiny (Jakoubek 2004: 218).

Další z představ kolujících v rámci těch složek institucionálního prostředí, které mají vliv na tvorbu a udržování sociálně a prostorově segregovaných prostor v českých městech při životě, je představa, že Romové tvoř́ jednotnou „komunitu“. V tomto prŕípadě se potvrzuje postřeh G. Baumanna, že „protagonisté dominantního diskurzu stylizují ,etnické‘ kategorie [čili Romy] do [romských] ,komunit" definovaných reifikovanou [romskou] ,kulturou“ “ (Baumann 1997: 213, závorky M. R.). V rámci dominantního diskurzu institucionálního prostředí českých měst se pojem komunity používá ve smyslu výše uvedené „,úžasně jednoduché rovnice“ Baumanna.

Sociální exkluze, respektive existence sociálně a prostorově segregovaných prostor, se, jak upozorňuje Zygmunt Bauman, vylučuje s pojmem komunity v soudobém sociálně vědním pojetí: „Život v ghettu nevytváří komunitu. Sdílení stigmatu a veřejného ponížení nepřemění trpící v bratry; posiluje vzájemný výsměch, opovržení a nenávist... zkušenost ghetta rozpouští vzájemnou důvěru ještě před tím, než [komunita - pozn. M. R.] dostala šanci zapustit kořeny“ (Bauman 2001: 121, 122). Shrnuto jinými slovy: „ghetto znamená nemožnost komunity“ (Bauman 2001: 122, kurzíva v původním textu).

Kulturní diference jsou v městském urbánním prostoru z pozice moci esencializovány „etnizovány“ $v$ tom smyslu, že nositelé určitých charakteristik jsou bez ohledu na svou vlastní sebe-identitu objekty různých externích konstrukcí jinakosti (Ratcliffe 2000: 181). Bývá jim apriorně přiřazována zejména etnická nálepka (identita) bez reflexe možnosti, že by mohli být členy etnicky indiferentních sociálních formací (Lozoviuk 1998, 2005) nebo že by se mohli nalézat $\mathrm{v}$ rámci etnicky indiferentního sociálního kontextu. Pojem etnické indiference tak, jak jej Petr Lozoviuk představuje ve svých textech, upozorňuje sociální badatele na skutečnost, že kolektivní identity, zejména ve společnostech nezápadního typu, mohou spočívat, a obvykle také spočívají, na jiných než etnických principech. Existují společnosti, které etnicitě přikládají malý nebo vůbec žádný význam; možná i proto, že samotný koncept etnicity vůbec neznají. A není se čemu divit: byli to Glazer a Moynihan, kteří v roce 1975 prohlásili, že „etnicita se zdá být novým termínem“ (Glazer a Moynihan 1975: 1) v tom smyslu, že se ve slovnících anglického jazyka objevuje až od 60. a 70. let 20. století.

\section{Diskurz a sociální a prostorová segregace}

Esencializace kulturních diferencí je princip, který odděluje sociální formace na základě jim připsané a údajně neměnné podstaty. Umožňuje pak mezi skupinami, které jsou definovány jako esenciálně odlišné, vztyčovat bariéry (sociální hranice), které na sebe v městském 
prostoru mohou brát podobu hranic fyzických (plot, zed' v Matiční či jiné ulici, separované unimo-buňky pro ,neplatiče“, periferie města či část průmyslové zóny oddělená př́rodní či umělou bariérou atd.). Pokud na sebe sociální hranice berou podobu hranic fyzických, bývají doprovázeny celými diskurzivními mytologiemi, které produkci a existenci takových hranic vysvětlují či ospravedlňují.

O skupinách, které jsou definovány jako esenciálně odlišné, se pak v rámci dominantního diskurzu vytvářejí specifické obrazy. Ty na sebe berou bud' vizuální, nebo textuální podobu a vždy hrají důležitou roli v konstrukci stereotypů (Sibley 1995: 28). Původní funkcí obrazu, jakožto snahy o znázornění světa, bylo dle filosofa Viléma Flussera (1994) zprostředkovat člověku svět. Jelikož se však staví mezi poznávajícího člověka a poznávaný svět, tak obrazy svět nezprostředkovávají, nýbrž zakrývají - patří to k jejich bytostné povaze (Flusser 1994: 9).

Význam mediálních obrazů pro konstrukci jinakosti, např́klad jinakosti Romů, spočívá také v tom, že „,mnozí lidé jsou bezpochyby zmateni některými tématy - někteří většinou témat -, jsou ale schopni čerpat ze své vlastní zkušenosti a z laického vědění spolu s mediálními fragmenty, aby jim dali smysl“" (Gamson a kol. 1992: 388). Pakliže však např́íklad členové institucionálního prostředí českých měst nemají osobní zkušenost s životní realitou členů kolektivit, o jejichž prostorovém umístění do určité míry rozhodují, musejí své ,znalosti““ - chtě nechtě - čerpat z běžně zaužívaných stereotypů a mediálních sdělení, na jejichž (re)produkci se zároveň sami často podílejí. Mediální reprezentace romských kolektivit tak často bývají imaginárními konstrukcemi, které mnohdy nemají žádný vztah k údajně popisované realitě (Radostný a Růžička 2006b). Pak zde ovšem platí upozornění, že „,mezi představami, fantaziemi a výkonem moci může být významné spojení“ (Sibley 1995: 49). Na sociální a prostorové segregaci se podílí nedostatek informací o „reálných“ exkludovaných skupinách a prostorech tím, že prázdné místo původně určené pro informaci o skutečnosti musí zaujmout obraz či mýtus. Obrazy a stereotypy vznikající o sociálních formacích, které jsou definovány, a proto i vnímány, jako odlišné, spolu-vytvářejí či pomáhají vztyčovat hranice mezi in-group a out-group. Vztyčování sociálních hranic spočívá v definování kritérií členství nějaké množiny objektů, přičemž tato kritéria, respektive hranice, určují, kdo do skupiny patří a kdo ne (Jenkins 1997: 80).

Na sociální a symbolický aspekt vytváření a udržování mezi-skupinových hranic, podél kterých dochází k vytváření kolektivních identit, obrátil v roce 1969 pozornost sborník textů Ethnic Groups and Boundaries, který editoval norský antropolog Frederik Barth (1969). Existence kulturních diferencí - zejména jejich udržování a zdůrazňování - se odehrává podél hranic těch skupin, které se vzájemně konceptualizují jako skupiny odlišné. Skupinové identity, jako je například etnicita, jsou tak vytvářeny v procesu kontaktu skupin - jsou to vztahové entity (Eriksen 1993: 9-10).

Na symbolický aspekt vztyčování hranic mezi skupinami upozorňuje také Jock Young (1999). Ten tvrdí, že sociální exkluze, jakožto způsob konceptualizace kulturních diferencí, vyplývá z materiálního a morálního charakteru doby (Young 1999: 78). Jedinci jsou prý v dnešní nejisté době sžíráni pocity ontologické a ekonomické nejistoty, což je dle Younga extrémně výbušná směsice produkující institucionální trestné reakce na deviantní nálepky a vedoucí $\mathrm{k}$ možnosti vytváření obětních beránků. Tváŕí v tvář ekonomické a ontologické nejistotě dochází k upevňování psychického bezpečí reafirmací hranic in-group, nebot' 
„out-group se stává obětním beránkem pro problémy širší společnosti: je to underclass, která žije v zahálce a kriminalitě“ (Young 1999: 20). Onu „underclass“ tvoří lidé, na které naše pozdní modernita a ekonomika zapomněly, které však nezapomněly exkludovat jako deviantní a jako esenciálně odlišné.

Že je sociální a prostorová exkluze v moderních městech důsledkem specifické konceptualizace (kulturních) diferencí, se domnívá také britský sociální geograf David Sibley (1995). Kořeny této konceptualizace však nehledá v ekonomických a ontologických nejistotách dnešní doby, nýbrž $\mathrm{v}$ ranné ontogenezi, respektive $\mathrm{v}$ průběhu socializace a intersubjektivní konstrukce identity. Čerpaje z psychoanalytické literatury (E. Erikson, C. Perin, J. Kristeva) a z teorií socializace symbolického interakcionismu (G. H. Mead) Sibley podporuje tezi, že klasifikace „my“ $\times$ „oni“, která tvoří symbolické jádro a princip udržování mezi-skupinových hranic, je pokračováním či rozvinutím primárnější klasifikace, dle které se v průběhu socializace vytváŕí jedincova identita. Tato primární klasifikace je „self“ $\times$ „other“ (já × jiný), která bývá v pozdějších fázích socializace projektována na společnost i na prostor (Sibley 1995: 86).

Psychická, respektive socializací podmíněná, avšak zprvu amorfní klasifikace „my“ $\times$ „oni“, jejímž předobrazem je primárnější klasifikace „self“ $\times$ „other“, na sebe bere konkrétní podoby až v konkrétních sociálních kontextech. Sociální kontexty, které tuto symbolicky plodnou dichotomii naplňují, jsou vytvářeny zejména diskurzivně; obrazy a stereotypy do nich vstupují jako aktivní činitelé. Zejména okolo Romů, jakožto členů domněle esenciálně odlišné skupiny, se v rámci dominantního diskurzu vytvořila celá mytologie takových obrazů.

\section{Povaha diskuzivní mytologie}

V diskurzivní mytologii tematizující Romy jsou v rámci dominantního diskurzu českých měst dle mého názoru významné tři momenty: (1) esencializace kulturních diferencí (která byla $\mathrm{v}$ textu již debatována), (2) diskurz čistoty a znečištění a (3) diskurzivní manipulace prostorem.

\subsection{Diskurz (ne)čistoty}

Pojmy vztahující se k čistotě a znečištění, at' již metaforicky či popisně, tvoří podstatnou komponentu dominantního diskurzu o Romech. Britská antropoložka Judith Okely ukazuje, jak bývá pojem čistoty používán ke vztyčování sociálních hranic jak gádži mezi nimi a Romy, tak i Romy (respektive Travellery-Cigány) mezi sebou (Okely 1975: 48). „Hygienickou“ komponentu diskurzu o Romech se pokusili zachytit na základě analýzy mediálního diskurzu o Romech v jednom středočeském městě Radostný a Růžička (2006b). Autoři se pokusili lokalizovat ikony, nejčastější motivy a klíčová témata mediálního diskurzu o lokálních romských sociálně vyloučených lokalitách. Mezi nejčastější ikony patřily, mimo jiné, tyto: (a) zdevastované či „vybydlené“ nemovitosti, (b) činění nepořádku nebo nepořádek samotný, (c) porušování norem a symbolického řádu. Mediální diskurz o Romech, který se selektivně zaměřuje zejména na situace, kdy dochází k porušování hygienických a estetických norem, často doprovázejí „šokujíci“ fotografie „,vybydlených“ domů, hromad odpadků, nepořádku apod. 
Pokud ne větší, tak minimálně stejný dopad na podobu dominantního diskurzu o Romech mají, vedle novinového a televizního zpravodajství, různé zpravodaje vydávané a distribuované na obecní úrovni. Ukázkovým příkladem může být článek ve Zpravodaji města Kraslic ze záŕí roku 2005 (Kraslice 2005). V článku „Proběhly dvě kontrolně bezpečnostní akce“, z nichž jedna spočívala $\mathrm{v}$ návštěvě policie $\mathrm{v}$ jedné ubytovně obývané především Romy, je popisováno, jak ,pracovníci městského úřadu Kraslice objevili pěknou řádku prohřešků“, přičemž mezi nejzávažnější patřily „odpadky rozeseté ve větších či menších hromadách kolem domu a množství dětí potulujících se po okoli'“ (Kraslice 2005: 2). Jako ilustrace byla k článku připojena fotografie pořízená na prostranství před vchodem příslušného domu, které bylo celé pokryto velkou hromadou nepořádku: starého rozbitého nábytku, nefunkčních elektrických spotřebičů a dalšího odpadu. Nešlo však o fotodokumentaci. Inkriminovaná fotografie pochází ze dne, kdy nájemníci na základě nařízení majitele nemovitosti vyklízeli místní sklepení. Veškerý odpad měl směřovat do přistaveného kontejneru, který měl majitel nemovitosti zajistit, avšak neučinil tak, a vše zůstalo ležet před domem na trávníku a na chodníku. Právě tehdy byla pořízena tato fotografie. Po několika dnech bylo město donuceno dopravit kontejner na vlastní náklady. ${ }^{2}$

Norský antropolog Harald Eidheim se domnívá, že pro porozumění mezi-skupinovým vztahům může být př́nosné věnovat pozornost způsobům, jakými jsou v různých kontextech diskurzivně manipulovány základní hodnoty, jako je např́iklad čistota (Eidheim 1969: 40). Pokud uvažujeme o tom, jaký vliv má diskurz na konceptualizaci Romů určitým způsobem, může být př́nosné věnovat pozornost způsobům, jakými se slovo cikán používá v běžné mluvě. Bulharští bohemisté Miglena Michaylova a Dončo Georgiev (Michaylova, Georgiev 2006) vyexcerpovali frazémy a idiomy s komponentem cikán z běžných výkladových a frazeologických slovníků (nejen) českého jazyka. Michaylova s Georgievem tvrdí, že ,jedna z typických představ o Romech, že jsou špinaví, také souvisí s konotací černé barvy. Vzhledem k tomu je... prrirovnání typu černý jako cikán možno aplikovat ve smyslu přirovnání typu špinavý jako cikán“" (Michaylova, Georgiev 2006: 146) a uvádějí celou řadu př́ikladů odrážející ,zobecnělou představu, že Romové jsou špinaví, otrhaní, že tam, kde bydlí, je nepořádek a zápach“ (Michaylova, Georgiev 2006: 147).

Je zřejmé, že řada ,hygienických“ momentů v rámci dominantního diskurzu o Romech není kvazi-fotografickým odrazem reality. Nejen proto, že kategorie vkusu a pořádku jakožto kategorie estetické variují a podléhají změnám napříč prostorem i časem, nýbrž i proto, že akt klasifikace je kognitivní činností založenou spíše na afektu a sentimentu, než na čistém intelektu (Durkheim, Mauss 1963: 86). Kategorizace jiných (např́klad jako špinavých) je součástí konstrukce vlastní identity (např́klad jako čistých) (srov. Jenkins 1997: 87); řečeno jinými slovy: vyjadřuji-li se hodnotově zatíženým způsobem o tom, jaký je někdo jiný, zároveň tím vyjadřuji i to, jaký já nejsem (nebo jak nechci být vnímán).

Členové institucionálního prostředí českých měst (nejen při přidělování bytů) často jednají na základě představ a obrazů zprostředkovávaných médii a zároveň tyto představy a obrazy svým jednáním posilují a utvrzují, jak dokládá i následující citace:

2 Za tento př́iklad mediální manipulace a dekontextualizace děkuji Lucii Kšandopérové a Lucii Plavjanikové, které v Kraslicích prováděly v inkriminovanou dobu terénní výzkum. 
Zde považujeme za nutné poukázat na situaci v Matiční ulici v Ústí nad Labem, kde magistrát odmítl do Matiční dopravit kontejnery, jejichž množství tam bylo naprosto nedostatečné. Úklid společných prostor, který zorganizovalo tamní komunitní centrum, tak narazil na neochotu úředníků, a dál se pak mohlo na Matiční ukazovat, jaký je tam strašný nepořádek.

(Peláková 2004: 90)

Na tomto místě lze vznést určité podezření, že nepořádek v lokalitách obývaných Romy je důsledkem určité definice situace, respektive sebenaplňujícího se proroctví (Merton 2000: 196-203), spíše než důsledkem ,přirozenosti“ obyvatel těchto lokalit. David Sibley tvrdí, že to jsou klíčové ideje špíny a nečistoty, co tvoří zárodek exkludujícího diskurzu tím, že tyto ideje pojí s určitým nedostatkem a podřadností (Sibley 1995: 14).

Britská sociální antropoložka Mary Douglas (1992 [1966]) považuje kategorie čistoty a znečištění za univerzální schéma artikulace sociálních klasifikačních systémů. Tak mají i v diskurzu o Romech kategorie čistoty a nečistoty spíše symbolický charakter, což lze podpořit existencí následujícího paradoxu. Romové bývají vykreslováni jako elementy produkující znečištění a špínu, ačkoli romské kolektivity jsou vnitřně organizované na základě mnohem tužších ,„pollution taboos“ než jaké jsou běžné u neromských společností v období modernity. ${ }^{3}$ Samotný vzájemný vztah romských kolektivit může z hlediska jejich vlastní perspektivy spočívat na principu (rituální) čistoty a nečistoty. Koncept rituální čistoty/nečistoty črtá nepřekročitelné hranice (nepřekročitelné žádným myslitelným zpơsobem - ani sňatkově, ani komunikačně, ani ekonomicky) uvnitř domnělé „romské komunity“. Tato skutečnost však zároveň ideu jednotné „romské komunity“, která by měla potenciál vystupovat jako jednolitý sociální celek, zpochybňuje (srov. Jakoubek 2004: 48-63).

O osobách ohrožených sociální exkluzí, respektive o osobách marginálních Mary Douglas tvrdí, že ,jsou jaksi opomíjeni v rámci modelu společnosti, nemajíce pevné umístění. Nemusí dělat nic morálně špatného, ale jejich status je nedefinovatelný“ (Douglas 1992: 95). Za marginální osoby v rámci západní společnosti pak Douglas považuje např́klad bývalé vězně a bývalé psychiatrické pacienty (Douglas 1992: 97). Problémy se sociálním začleněním bývalých vězňủ a bývalých psychiatrických pacientů do konvenční společnosti, spolu s obdobnými problémy sociálně vyloučených osob a rodin, pravděpodobně souvisejí s univerzálně podobnými reakcemi na marginalitu, ambivalenci a nedefinovatelnost. Nečistota, která je „residuální kategorií, odvrhnutou z našich normálních klasifikačních schémat" (Douglas 1992: 36), právě svojí nemístností, hraničností a nedefinovatelností generuje pocity ohrožení: „nečistota je specifická třída nebezpečí“ (Douglas 1992: 98). Pocity znečištění respektive pocity nebezpečí či ohrožení (a potřeba purifikace, která z pocitu znečištění/nebezpečí pramení) se objevují tehdy, když dochází k narušování symbolických klasifikačních schémat „,nemístnými“ prvky.

\subsection{Diskurz a prostor}

Na prostorové komponentě diskurzivní mytologie o Romech se ukazuje, že prostor má i v moderní společnosti stále významný symbolický potenciál, zejména pak na rovině mezi-skupinových vztahů.

Rituální čistotou a znečištěním v rámci symbolismu Travellerů-Cigánů se podrobněji zabývá Judith Okely (1992 [1982]: 77-104). 
Michel Foucault předložil v roce 1967 typologii prostoru, ve které staví na jednu stranu prostor utopický, na stranu druhou pak prostor heterotopický, jakožto prostor ,naprosto jiných míst“ (Foucault 1996 [1967]: 76). „Nejprve jsou tu utopie. Utopie jsou umístěním bez skutečného místa... Utopie, to je dokonalá společnost sama, anebo společnost převrácená; utopie jsou však v každém případě místa zásadně neskutečná“ (Foucault 1996: 76). Za Utopii par excellence v rámci dominantního diskurzu o Romech snad lze považovat Indii, jakožto místo jejich původu a domova.

Většina odborných i kvazi-odborných pojednání o Romech jsou pojednání většinou diachronní, historická a jazykově evoluční. Zdůrazňují (pomyslnou) historickou vazbu na Indii, jakožto místo „skutečného“ domova, původu a odchodu Romů. Ačkoli lze vztah stovky let staré jazykové historie k současnému neutěšenému sociálnímu stavu považovat za problematický minimálně v oblasti kauzálních souvislostí, bývají Romové stále znovu zobrazováni jako kočovníci, kteří přišli z Indie: „Třebaže naprostá převaha Romů již několik set let žije usedlým životem, udrželo se kočovnictví jako znak a symbol romského národa. S jeho manifestací prostřednictvím kola vozu se můžeme například setkat i na romské (národní) vlajce“ (Hirt, Jakoubek 2003: 64). Lingvisticko-historizující pohled na Romy zastává většina uznávaných autorit v oboru romistiky, např́iklad Angus Fraser (1998), Ian Hancock (2001) či Ctibor Nečas (2002), jejichž poznatky shrnuje Milena Hübschmannová tvrzením, že „o Romech se ví zcela jistě zatím jen to, že pocházejí z Indie“ (Hübschmannová 2000: 20). Státem podporované budování obrazu Romů jako kočovníků, kteří přišli z Indie, se pak v souběžné snaze o integraci těchto lidí do české (teritoriální a principielně nekočovné) společnosti může jevit jako počin možná poněkud problematický.

Dominantní diskurz, mezi jehož participanty patří (bohužel) i řada badatelů působících na akademické půdě, (re)produkuje mýtus o Romech jako o národu kočovníků, kteří přišli, respektive odešli, z Indie, a tento fakt staví jako podstatnou část jejich identity. Na tuto komponentu diskurzivního mýtu o Romech odkazuje i charakter frazémů a idiomů s komponentem cikán ve frazeologických a výkladových slovnících různých jazyků. Významnou součástí dominantního diskurzu o Romech je ikona kočovnictví, s kterou „souvisí jedna z rozšiřrených představ o nich (o Romech - pozn. M. R.), že nemají svou vlast, domov, že se toulají po světě chudí a hladoví... (například) vést cikánský život... toulat se po světě jako cikán..." (Michaylova, Georgiev 2006: 147).

Romové jsou v rámci dominantního, ale často i v rámci vědeckého diskurzu neúnavně prezentováni jako skupina „kočovníkư“ či lidí „bez domova“, jako skupina, která nemá žádnou konkrétní ,přirozenou“ lokaci v prostoru. Romové jsou prezentováni tak, jako kdyby byli skrze svoji notoricky ne-teritoriální (Hirt, Jakoubek 2003: 64) historii a povahu v rámci přísně teritoriálních ne-kočovných kosmografií „,nemístní“. Představa prostorové „nemístnosti“ kočovných Romů může dopadnout na symbolicky plodnou půdu zejména v souvislosti s prostorovou imaginací ne-kočovné „neromské“ společnosti, která konkrétni prostorovost (ale i stabilitu a permanenci) ověnčuje symbolicky bohatými a hodnotově zatíženými významy.

Na symbolický a rituální rozměr prostoru v moderních společnostech upozornila řada autorů. Např́iklad Foucault tvrdil, že: 
Navzdory všem technikám, které se zmocňují prostoru, navzdory celé struktuře poznání, které nám prostor umožňuje vymezit či formalizovat, dnešní prostor snad ještě není zcela desakralizován [...]. Je jisté, že došlo k určité teoretické desakralizaci prostoru (té, kterou svým dílem naznačil Galileo), ale možná jsme přece jen nedospěli k praktické desakralizaci prostoru. Snad je náš život ještě stále veden množstvím protikladů, které zůstávají nedotknutelné, které se naše instituce a praxe ještě neodvážily zničit.

(Foucault 1996: 73-74)

Právě v protikladech, o kterých hovoří, dochází dle Foucaulta k oživování skryté př́itomnosti posvátného. $Z$ vědomí nedokonalé desakralizace prostoru v moderních společnostech vychází i Mircea Eliade. Ten v knize Posvátné a profánní (1994 [1957]), ve které se zabývá náboženským rozměrem zkušenosti času a prostoru archaického člověka, upozorňuje na to, že „,cosi z tradičního pojetí Světa přetrvává dosud i v jeho chování [v chování moderního člověka - pozn. M. R.], třebaže si není vždy vědom tohoto dědictví, jehož původ sahá do nepaměti“" (Eliade 1994: 37).

Prostorová klasifikační schémata mají klíčový význam nejen pro organizaci (moderního městského) prostoru, nýbrž pro organizaci lidské společnosti vůbec. Dle Roberta Hertze (1973 [1909]), významného představitele durkheimovské sociologické školy, jsou primární sociální klasifikace klasifikacemi prostorovými. Jak napsal Émile Durkheim: „Uspořádání společnosti ... bylo vzorem uspořádání vesmíru a jeho znázorněním“ (Durkheim 2002 [1912]: 20). Byli to tedy zástupci francouzské sociologie Robert Hertz a Émile Durkheim, kdo upozornil na nedílnost sociálního a prostorového.

Foucaultova typologie utopie $\times$ heterotopie označuje prostory, které mají v imaginaci každé společnosti specifické postavení. Na jedné straně stojí prostory utopické, na straně druhé pak prostory heterotopické, prostory ,jiné“. Ty označují místa, která jsou sférou „,proti-umístění“ - jsou sférou reprezentace, zároveň však popírání a převracení (Foucault 1996: 76). Heterotopické prostory hrají významnou symbolickou úlohu zejména v rámci rituálů. Heterotopie současné západní civilizace nazývá Foucault „,heterotopiemi úchylky“. Do nich „se umist’ují jednotlivci, jejichž chování je odchýlené vzhledem k požadovaným prostředkům či normám“ (Foucault 1996: 78). Řečeno jinými slovy:

Minority, „nedokonalí“ a ostatní, kteří jsou definováni jako ti, kdo ohrožují dominantní společenskou skupinu [...], bývají umist'ováni ,jinam“. Toto ,jinam“ může znamenat „,nikde“ v prŕpadě genocidy či pokusu o morální nápravu devianti̊, nebo může být ono ,jinam“ nějakou prostorovou periferií, jakou je hranice světa či hranice města.

(Sibley 1995: 49)

Dle Foucaulta patří mezi heterotopie úchylky např́iklad domy pro přestárlé a domovy důchodců, psychiatrické ústavy či věznice. Mezi „heterotopie úchylky“ současných českých měst snad lze dle mého názoru zařadit i různé „ubytovny pro neplatiče“, holobyty, azylové domy, nechvalně proslulé městské čtvrtě (eufemisticky nazývané „Bronxy“ apod.) či jiná odkladiště „deviantních“ jedinců a skupin; heterotopie (úchylky) snad právě proto tak úzce souvisí s konceptem anomie (Lefebvre 2003: 129). Téměř v každém městě ,jsou prostory, které jsou relativně jednoduše identifikovatelné a které jsou určeny pro ,nečisté‘ a pro ty, kteří budou vyloučeni,“ jak tvrdí Sibley (1995: 53). 
Argument vyplývající z předchozího textu zní, že to je průsečík prostorové a sociální klasifikace, na kterém dochází k otevírání potenciality socio-prostorové exkluze. K naplnění této potenciality může dojít teprve tehdy, když dojde k překrytí sociálních kategorií ,jiných““ lidí a ,jiných“ prostor, jak se domnívá i David Sibley (1995: 69).

\section{Exkluze jako forma sociální kontroly}

Socio-prostorovou exkluzi přítomnou v českých městech lze dle mého názoru chápat jako specifickou formu sociální kontroly prováděnou prostřednictvím tzv. prostorové purifikace. Tu je zároveň možné obecně považovat za klíčový aspekt organizace sociálního prostoru (srov. Sibley 1995: 77). Za socio-prostorovou exkluzí se skrývá symbolická snaha o udržení dominantního kulturního řádu tváří v tvář negativně definovaným sociálním skupinám a jejich nebezpečným, respektive nečistým alternativním kulturním řádům. Snahu o prostorovou kontrolu deviace je možné ilustrovat na řadě př́padů. Prostituce bývá kontrolována prostorově uvnitř tzv. „red-light districts“. Porušení psaných norem - zákonů - může vést do vězení. Porušování „dobrých mravů“, k němuž se řadí např́íklad odlišný estetický vkus, chudoba a dlouhodobá nezaměstnanost spolu s tzv. „etnickou definicí situace“ ze strany dominantního diskurzu (Růžička 2006: 141-142), zdá se, vede do ghetta.

O purifikačních rituálech lze v douglasovském smyslu hovořit jako o způsobech odstraňování abnormalit a ne-místných prvků z prostoru, který těmto prvkům v rámci daného symbolického řádu není určen. „Nemístné“ prvky jsou umist’ovány do prostoru, který jim daným symbolickým řádem vymezen je. ,Jiný“ k ,jinému“. Tento douglasovský moment tvoří i podstatu „purifikace“ sociálního prostoru v současných českých městech. Takovýto proces má řadu negativních důsledků, zejména pak v podobě narůstajícího počtu sociálně (a ,etnicky“) a prostorově segregovaných lokalit.

\section{Závèr}

Socio-prostorovou exkluzi považuji na základě výše uvedených argumentů za formu sociální kontroly a za způsob udržování dominantního symbolického a kulturního řádu tváři v tvář negativně pocit’ovaným kulturním alternativám skupin definovaných jako esenciálně odlišné. Během procesů kontroly a reprodukce řádu jsou mezi esenciálně definovanými kolektivitami vztyčovány a udržovány sociální a prostorové hranice a dominantní kulturní a hodnotový řád je chráněn odstraňováním alternativ, respektive „,abnormalit“،, které údajně mohou ohrozit jeho stabilitu.

Významný moment zde hraje manipulace prostorem a společností, během které jsou skupiny definované jako ,jiné“ (odlišné) pohybovány prostorem (tj. stěhovány z jednoho místa na jiné či ,jiné“), čímž je, mimo jiné, manifestována mocenská hierarchie nadřazenosti a podřazenosti mezi těmito skupinami. Kontrola a purifikace prostoru se stává významným aspektem sociální kontroly a manifestace moci a dominance v městských společnostech; vždyt' „,prostor má základní význam ve všech formách společenského života; prostor má základní význam v každém uplatňování moci““ (Foucault 2000: 39). 
Exkludované „komunity“ a exkludovaný prostor jsou nedílnými součástmi kosmografie moderní městské společnosti. Součástí urbánních geografíi jsou ,jiné prostory“, které zaujímají v symbolické (a prostorové) imaginaci specifické postavení. Prostor městský bývá klasifikován na základě stejného principu jako prostor sociální, a to dle prvotní identitární diference „self“ $\times$ „other“. Tato prvotní diference je projektována na mezi-skupinové vztahy i na prostor. Překrytím klasifikací sociálních a klasifikací prostorových, čili překrytím ,jiných“ sociálních skupin a ,jiných“ prostor, je umožněna socio-prostorová exkluze. Je to proces, který bývá často nepovšimnutou, avšak zdá se, že nedílnou komponentou městského života.

Jedním z výchozích předpokladů tohoto textu bylo, že v rámci městského prostředí je možné studovat sociální vztahy skrze jejich vzájemné prostorové umístění. Součástí takového studia pak může být zaměření pozornosti $\mathrm{k}$,jiným prostorům“, jež jsou do tváří měst zapouštěny tzv. „techniky prostoru“ osobami, které jsou pověřeny rozvojem území (Foucault 2000: 32). V rámci plánů městského rozvoje, které se také mohou podílet na prostorové a sociální segregaci (srov. Rabinow 1995: 2-4), jsou do (městského) prostoru zakomponovány „jiné prostory“. Těch se rozvoj sice netýká, během (re)konstrukce a rozvoje měst jsou však brány v potaz, je s nimi kalkulováno. Udržují si své specifické místo a do organizace urbánního prostoru a společnosti vstupují tím, že ovlivňují úvahy o architektonické úpravě prostoru. Architektura (v rámci rozvoje měst) je „politickým“ prvkem v tom smyslu, že „,zabezpečuje určité rozmístění lidí v prostoru, usměrňuje jejich oběh a kodifikuje vztahy, co mezi sebou udržuji“" (Foucault 2000: 40).

Organizace prostoru sestává ze dvou úrovní - estetické a disciplinární (Rabinow 2003: 355). „Jiné prostory“, jakožto klíčový prvek v rámci disciplinární organizace městského prostoru, jsou tak strategickou součástí mocensky nerovných mezi-skupinových vztahů stojících na principu dominance a podřízenosti. Jejich existence, beroucí na sebe podobu mimo jiné „etnicky“ a prostorově segregovaných lokalit, klade prostorové překážky pro sociální kontakt a komunikaci mezi dominantní skupinou a skupinami podř́zenými, které jsou dominantním diskurzem definovány jako odlišné/,jiné“. Prostorové bariéry znesnadňující sociální kontakt vytvářejí během pokusů o reprezentaci sociálních kolektivit definovaných jako „jiných“ potřebu sahat do zbrojnice (nejen mediálních) obrazů a stereotypů.

Prostorové a sociální klasifikace tíhnou ke vzájemné korelaci. Ideje tak abstraktní, jako je čas a prostor, ,jsou v každém momentu své existence propojeny s př́slušnou sociální organizaci' (Durkheim, Mauss 1963: 88). Z toho vyplývá, že praxe vedoucí k exkluzi a segregaci určitých osob a skupin nemusí být nutně „logickým“ důsledkem jejich jednání, nebot' logické kategorie a hierarchie jsou pouze jiným aspektem sociálních kategorií a hierarchí (Durkheim, Mauss 1963: 83-84). Praxe (sociální) exkluze takto může být vnímána jako důsledek vyplývající z nevědomého uplatňování symbolických klasifikačních schémat.

Organizace městského prostoru je nedílnou součástí sociální kontroly (ochrany dominantního kulturního řádu) a umožňuje takové procesy, jako je kulturní dominace, hegemonie prostoru či sociální exkluze. Domnívám se, že tyto funkce organizace městského prostoru nejsou nevyhnutelné. Pokud sociální inkluze spočívá na rovném př́istupu ke zdrojům, k rozhodovacím procesům a ke společným naracím (Madanipour 2003: 188), pak může být proces sociální inkluze podpořen citlivou revizí prostorových (a tím i sociálních) bariér v rámci plánování městské výstavby a rozvoje (např́íklad Maier 2005) či v rámci uvažování o prostoru obecně. 


\section{Literatura}

Baršová, A. 2002. „Problémy bydlení etnických menšin a trendy k residenční segregaci v České republice." In P. Víšek (ed.) Romové ve městě. Praha: Socioklub.

Barth, F. (ed.) 1969. Ethnic Groups and Boundaries. Oslo: Universitetsforlaget.

Bauman, Z. 2001. Community. Seeking Safety in an Insecure World. UK: Polity Press.

Baumann, G. 1997. „Dominant and Demotic Discourses of Culture: Their Relevance to Multi-Ethnic Alliances.“ In P. Werbner, T. Modood (eds.) Debating Cultural Hybridity. London: Zed Books.

Douglas, M. 1992 [1966]. Purity and Danger. London: Routledge and Paul Kegan.

Durkheim, É. 2002 [1912]. Elementární formy náboženského života. Praha: Oikoymenh.

Durkheim, É.; Mauss, M. 1963 [1903]. Primitive Classification. London: Cohen \& West.

Eidheim, H. 1969. „When Ethnic Identity is a Social Stigma.“ In F. Barth (ed.) Ethnic Groups and Boundaries. Oslo: Universitetsforlaget.

Eliade, M. 1994 [1957]. Posvátné a profánní. Praha: Křest’anská akademie.

Eriksen, T. H. 1993. Ethnicity and Nationalism: Anthropological Perspectives. London: Pluto Press.

Flusser, V. 1994. Za filosofii fotografie. Praha: Nakladatelství Hynek.

Foucault, M. 1996 [1967]. „O jiných prostorech.“ In M. Foucault Myšlení vnějšku. Praha: Herrmann \& synové.

Foucault, M. 2000 [1982]. „Priestor, vedenie a moc.“ In M. Foucault Moc, subjekt a sexualita. Bratislava: Kaligram.

Fraser, A. 1998. Cikáni. Praha: Nakladatelství Lidové noviny.

Gamson, S. a kol. 1992. „Media Images and the Social Construction of Reality.“ Annual Review of Sociology, 18: 373-393.

Glazer, N.; Moynihan, D. 1975. „Introduction.“ In N. Glazer, D. Moynihan (eds.) Ethnicity: Theory and Experience. Cambridge (MA, USA): Harvard University Press.

Hancock, I. 2001. Země utrpení. Praha: Signeta.

Hertz, R. 1973 [1909]. ,,The Pre-eminence of the Right Hand: A Study in Religious Polarity.“ In R. Needham (ed.) Right and Left. Essays on Dual Symbolic Classification. Chicago: The University of Chicago Press.

Hirt, T.; Jakoubek, M. 2003. „Konstruktivistická analýza romské nacionální mýtotvorby.“ In M. Jakoubek, O. Poduška (eds.) Romské osady v kulturologické perspektivě. Brno: Doplněk.

Hübschmannová, M. 2000. „K počátkům romských dějin.“ In Černobílý život. Praha: Galery. Jakoubek, M. 2004. Romové - konec (ne)jednoho mýtu. Praha: Socioklub.

Jára, M. a kol. 2006. Sociální diskriminace pod lupou. Metodika identifikace diskriminačního jednání a doprovodných negativnich jevů v bydlení a zaměstnávání. Praha: Otevřená společnost, o.p.s.

Jenkins, R. 1997. Social Identity. London: Routledge.

Klíčová, K. 2004. „Podmínky bydlení př́íslušníků romské komunity jako marginalizované sociální skupiny a rezidenční segregace.“ In I. Šimíková, I. Vašečka (eds.) Mechanismy sociálního vyčleňování romských komunit na lokální úrovni a nástroje intergrace. Brno: Barrister \& Principal. 
Kraslice 2005. „Proběhly dvě kontrolně bezpečnostní akce.“ Zpravodaj města Kraslic. 2005, č. 9 (záríi).

Lefebvre, H. 2003 [1970]. The Urban Revolution. Minneapolis: University of Minnesota Press.

Lozoviuk, P. 1998. „K problematice etnické indiference.“ Český lid, 84, č. 3: 201-212.

Lozoviuk, P. 2005. „Etnická indiference a její reflexe v etnologii.“ In M. Jakoubek, T. Hirt (eds.) Soudobé spory o multikulturalismus a politiku identit (antropologická perspektiva). Plzeň: Nakladatelství Aleš Čeněk.

Madanipour, A. 2003. „Space and Social Exclusion.“ In R. T. LeGates, F. Stout (eds.) The City Reader. London: Routledge.

Maier, K. 2005. „Možnost využití nástrojů územního plánování pro prevenci segregace.“ In L. Sýkora, J. Temelová (eds.) Prevence prostorové segregace. Praha: UK, Př́rodovědecká fakulta. On-line dokument [cit. 24. 8. 2006] dostupný z: www.mmr.cz/upload/files/ 060420_Publikace_segregace.pdf

Merton, R. 2000. Studie ze sociologické teorie. Praha: Sociologické nakladatelství.

Michaylova, M.; Georgiev, D. 2006. „Etnonyma

AH H / CIKÁN / CIGANIN / AH H v bulharštině, češtině, chorvatštině a srbštině. “ In L. Lenk, M. Svoboda, M. Jakoubek, K. Kučerová (eds.) Argonauti za obzorem západu. Ústí nad Labem: Nakladatelství a vydavatelství Vlasty Králové.

Moravec, Š. 2006. „Nástin problému sociálního vyloučení romských populací.“ In T. Hirt, M. Jakoubek (eds.) „Romové“ v osidlech sociálního vyloučení. Plzeň: Vydavatelství a nakladatelství Aleš Čeněk.

MPSV. 2006. Analýza sociálně vyloučených romských lokalit a absorpční kapacity subjektů působicich v této oblasti. On-line dokument [cit. 15. 9. 2006] dostupný z: www.mpsv.cz/ files/clanky/3043/Analyza_romskych_lokalit.pdf

Nečas, C. 2002. Romové v České republice včera a dnes. 5. vydání. Olomouc: Univerzita Palackého v Olomouci.

Okely, J. 1975. „Gypsy Identity.“ In B. Adams (ed.) Gypsies and Government Policy in England. London: Heineman Educational Books.

Okely, J. 1992 [1982]. The Traveller-Gypsies. Cambridge: Cambridge University Press.

Peláková, K. 2004. „Materiální podmínky př́slušníků romských komunit z pohledu teorií sociální exkluze a kultury chudoby.“ In I. Šimíková, I. Vašečka (eds.) Mechanismy sociálního vyčleňování romských komunit na lokální úrovni a nástroje intergrace. Brno: Barrister \& Principal.

Pierson, J. 2002. Tackling Social Exclusion. London: Routledge.

Rabinow, P. 1995. French Modern: Norms and Forms of the Social Environment. Chicago: University of Chicago Press.

Rabinow, P. 2003. „Ordonnance, Discipline, Regulation: Some Reflections on Urbanism.“ In S. Low, D. Lawrence-Zúníga (eds.) The Anthropology of Space and Place. Oxford: Blackwell Publishing.

Radostný, L.; Růžička, M. 2006a. „Masokombinát Kladno: výzkumná zpráva.“ In T. Hirt, M. Jakoubek (eds.) „Romové“ v osidlech sociálního vyloučení. Plzeň: Vydavatelství a nakladatelství Aleš Čeněk. 
Radostný, L.; Růžička, M. 2006b. „Terénní výzkum v hyperrealitě. Poznámky k mediální konstrukci sociálně vyloučené lokality.“ In T. Hirt, M. Jakoubek (eds.) „,Romové “v osidlech sociálního vyloučení. Plzeň: Vydavatelství a nakladatelství Aleš Čeněk.

Ratcliffe, P. 2000. „Is the Assertion of Minority Identity Compatible With the Idea of a Socially Inclusive Society?““ In D. Askonas, A. Stewart (eds.) Social Inclusion. Possibilities and Tensions. Basingstoke: Macmillan Press.

Ratcliffe, P. 2004. Race, Ethnicity and Difference: Imaging the Inclusive Society. Maidenhead: Open University Press.

Robinson, D. 2002. „Missing the Target? Discrimination in the Allocation of Social Housing.“ In P. Sommerville, A. Steele (eds.) „Race“, Housing \& Social Exclusion. London: Jessica Kingsley Publishers.

Růžička, M. 2006. „Sociální exkluze v Plzni.“ In Š. Waisová (ed.): Bohatství a chudoba v současném světě. Plzeň: Vydavatelství a nakladatelství Aleš Čeněk.

Sibley, D. 1995. Geographies of Exclusion: Society and Difference in the West. London: Routledge.

Soja, E. 1980. „The Socio-Spatial Dialectic.“ Annals of the Association of American Geographers, č. 70: 207-225.

Soja, E. 1989. Postmodern Geographies: The Reassertion of Space in Critical Social Theory. London: Verso.

Young, J. 1999. The Exclusive Society. London: Sage Publications.

Wacquant, L. 2004. „Ghetto.“ In N. J. Smelser, P. B. Baltes (eds.) International Encyclopedia of the Social and Behavioral Sciences. London: Pergamon Press. On-line dokument [cit. 1. 8. 2006] dostupný z: http://sociology.berkeley.edu/faculty/wacquant/wacquant_pdf/ GHETTO-IESBS.pdf

Wirth, L. 1938. „Urbanism as a Way of Life.“ American Journal of Sociology, 44, no. 1: $1-24$.

\section{Autor}

Michal Růžička působí na Katedře sociologie FF ZČU v Plzni a zároveň je doktorandem na Katedře antropologie na téže instituci. Zabývá se studiem teorii (sociální) exkluze a terénním výzkumem praxe segregace a exkluze v České republice i na Slovensku. Kontakt: mruzicka@kss.zcu.cz 